\title{
形成的評価を加味したパフォーマンス課題を取り入れた理科授業開発 一中学生の地学分野における進化概念形成を事例として一
}

\begin{abstract}
【要
約】

中学校 1 年理科教科書における地学分野には, 古生代から新生代に至る進化の証拠である 化石資料が登場する。ここでは「どのようにして進化してきたか」の解説がないまま，事実 だけが列挙されている。一方，「進化」に関する誤解は多く，根強く保持される誤概念を指 摘する先行研究も多い。本研究では開発した授業によって, 中学生の科学的進化概念がどの 程度形成されたかを検討することを目的とした。具体的には，進化に関する「本質的な問 い」を毎時の授業に設定し，その総括的評価として「絵」と「文」で表現する「パフォーマ ンス課題」を準備した。さらにパフォーマンス課題の作成前後に, 対話的な学びによる再考 と修正の機会，すなわち相互評価などの形成的評価の要素を教授・学習過程に加味した。パ フォーマンス課題や質問紙調查の結果から分析を加えたところ, 中学生の科学的進化概念の 理解に一定の効果がみとめられた。
\end{abstract}

[キーワード] 中学校理科地学分野，進化概念，逆向き設計，パフォーマンス課題，形成的評価

\section{1. 問題の所在}

現行中学校 1 年理科教科書（塚田ら, 2016a）にお ける「地球の歴史 (地学分野)」の単元には, 古生 代から新生代に至る進化の証拠である化石資料が登 場する。ここでは「どのように生物が進化してきた のか」の説明がないまま, 進化の事実だけが列挙さ れている。進化に関する解説, すなわち類縁関係な どの進化の証拠は, 現行では中学校 2 学年, 新学習 指導要領では 3 学年にゆだねられている（文部科学 省, 2017)。しかも「学校現場で生徒の活動（実験・ 観察, 課題研究や探究活動など）を通して進化を取 り扱うことは特に困難である」と指摘され（佐藤・ 大鹿, 2005), 中学校での生物進化の学習を効果的に 進める実験は少なく, 結果として資料をもとにして, 個々の教師の力量で進められることが多い（森本, 2009 ; 西野・佐竹, 2013)。さらに, 現代進化学では 否定されている「ラマルク説（獲得形質の遺伝）」の 支持者が中学生から大学生までのどの段階でも多く,

\footnotetext{
1 大阪市立下福島中学校 (兵庫教育大学大学院連合 学校教育学研究科)

${ }^{2}$ 兵庫教育大学
}

特に高校生物を学んだ後も保持しやすい誤概念であ ると指摘する知見もある（福井・鶴岡, 2001 ; 森本・ 甲斐・森藤, 2006 ; 中井, 2004)。その他, 「進化」 は「成長」「変身」「発達」「進歩」などと誤解されや すいとする先行実践も多く存在する（桐生，2004； 宮本, 2008 ; 正本・西野, 2011)。

一方，一般社会に目を移すと，進化の「進んでい る」という語が「進歩」や「優れている」と混同さ れ, 誤解・差別・偏見を生む学習内容であるとする 見解もある（石川・森，2002）。例えば，自然選択は 「自然淘汰・断種・生存競争・弱肉強食」など社会進 化論的に解釈される。それ故，「進化を教えることは 難しい」という指摘にもつながる（長谷川, 2004）。

現行の中学校学習指導要領では, 中学校 2 年にお ける「生物の変遷と進化」の単元目標には「現存の 生物や化石の比較などを基に, 現存の生物が変化し て生じてきたものであることを体のつくりと関連付 けてとらえること」と書かれている（文部科学省, 2008)。また, 新学習指導要領では, 中学校 3 年にお ける「生物の種類の多様性と進化」の単元目標には 「現存の生物及び化石の比較などを通して, 現存の多 様な生物は過去の生物が長い時間の経過の中で変化 
して生じてきたものであることを体のつくりと関連 付けて理解すること」と書かれている（文部科学省, 2017)。どちらもほぼ同様のことを述べているが，新 学習指導要領には,「多様な」と「長い時間の経過の 中で」という点が現行と異なっており, 上記の「成 長・変身・発達・進歩」などと, 科学的生物進化と の相違点が一層強調されているように思われる。

そこで本研究では, 中学生に対する科学的進化概 念形成に向けて, その進化の基本的メカニズムを理 解させることを目的とした。この 1 年地学分野にお ける「進化」に関する単元目標は学習指導要領には 元々存在しない。そのため, 中学校 2 年理科教科書 の生物分野に掲載されている「進化の定義：生物が 長い時間の間にしだいに変化し, 新しい生物が生じ ること」や「読み物：自然選択説」を参考に（塚田 ら, 2016b), これらに中学校 1 年生でも理解可能な 「変異」と「適応」を加えて, 表 1 のような「到達目 標」を設定した。

\section{表 1 到達目標：中学校 1 年地学分野}

(1) 生物は「環境の変化に適応」して進化する。 生物進化は一世代で起こらず, 長い世代を経て起こる変 化である（変異は新しく子が生まれるときに起こる）。

\section{2. 授業計画の理論的支柱と授業開発 \\ 2.1 形成的評価を加味した教授・学習過程}

具体的な学習内容には, 「何が進化か, 非進化か」 「進化は一世代か, 数世代か」「変異は一生の間（獲 得形質の遺伝）か，子が生まれるとき（突然変異） か」など, 二項対立による「本質的な問い」を準備 した。そして，その課題を対話的な学びによって解 決し, 自己評価や教師による評価などの形成的評価 をほぼ毎時にわたって実施する授業を提案した。

本研究では主に「逆向き設計」による方法を用い て授業を計画した。「逆向き設計」とは, 求められて いる結果を明確にし(第1段階), そのことを承認で きる証拠を決定してから (第 2 段階), 学習経験と指 導を計画する（第 3 段階）という 3 段階で構成され， 学習計画の前に評価の構想を行うという点が, 従来 のカリキュラム設計とは逆になっているためにこう 呼ばれる（Wiggins \& McTighe, 2005 ; 遠藤, 2005 ； 西岡，2005）。

以上の 3 段階を表 2 のようにまとめ, 加えて, 図 1 の左にその各段階を簡略化して図示した。そして， 図 1 の右側には「逆向き設計」において, 従来から 通常捉えられている要素 (目標 $\Rightarrow$ 本質的な問い $\Rightarrow$ 総
括的評価としてのパフォーマンス課題）を右上部に, 本研究において加味した「形成的評価」の要素を右 下部に，それぞれ枠で囲んで示した。つまり，ここ での特長は 1 つめの「パフォーマンス課題 (絵)」実 施直後に,「生徒発表の機会 : 自己評価・相互評価」, 及び「作品再考・修正の機会：自己評価・教師によ る再評価」を設定したことが通常の逆向き設計との 違いである。ブランスフォードらは「理解のフィー ドバックが形成的評価には不可欠で，そのためには 生徒に友だちの作品や自分の作品を評価させること が必要であり，例えば個人のパフォーマンスをその 場でモニターし，評価結果を直ちに生徒にフィー ドバックすることが重要である」と報告している (Bransford, Brown \& Cooking, 2000, p. 140)。この知 見を踏まえ, 図 1 のように 2 つのパフォーマンス課 題を挟んで「教授・学習過程」を確保し, これを本 研究では特に「加味した形成的評価」として, 以下 に議論を進めていくことを断っておく。このプロセ スによって, 1つめの「パフォーマンス課題 (絵)」 で生じた「フィードバック」を，次の 2 つの「パ フォーマンス課題（文)」に直接的に生かすことが可 能となると考えられる。そして, 生徒たちが自己調 整的により高い段階に進めるものと思われる。

\section{表 2 「逆向き設計」の3 段階}

【第 1 段階】（求められている結果）

(1) めざしている理解は学問の中心にあり, 永続的

(2) 深い思考と転移を促進する本質的な問い

(3) 本質的な問いは刺激的で論争的

【第 2 段階】（評価のための証拠）

(1) 実際の社会の中で使えるパフォーマンス課題

(2) 生徒や教師にフィードバックできる評価

(3) 自己評価の機会

【第 3 段階】（学習計画）

(1) 重大な概念の掘り下げに引き込まれる活動

(2) 作品を再考し, 修正し, 洗練する十分な機会

(3) 本質的な問いを軸にしたカリキュラム設計

\section{2 逆向き設計による授業開発}

「歴史を語る化石：地質年代の区分と生物の移り 変わり（塚田ら，2016a）」は生徒たちが最も興味を 持つ分野である。この 1 年次の学習を 2 年次「生物 の移り変わりと進化」につながる進化の導入編とし て, 表 2 の「逆向き設計の 3 段階」に基づいて表 3 のように計画し, 通常の中学校理科カリキュラムに 組み込んだ（追加したカリキュラムは表 3 の左欄に 下線で示した)。この中学校 1 年地学分野における実 
践は, 2017 年 4 月 28 日〜 5 月 12 日に公立 A 中学校 2 学級在籍 70 名（男子 38 名・女子 32 名）に対して 実施した。尚, この 2 学級の学級編成にあたっては, 前年度の 5 教科成績に基づいて行われており，ほぼ 等質とみなすことができる（2017 年度に 4 回実施 した理科定期テストの 2 学級の平均点は, それぞれ 63.2 点と 61.7 点であった)。

本研究の目的は「到達目標（表 1)」にあるよう に,「環境への適応」,「進化は世代を超えて起こる変 異」についての基本的な進化概念の習得である。こ の 2 点を踏まえて表 2 の【第 1 段階】や【第 3 段階】 にある，「本質的な問い」を各時限に設定した。例 えば，表 3 の【設問(1)〜6】のように進化に関する 「深い思考を引き起こし, 転移を促進する」, 「刺激 的で論争的な」課題を設定している。この課題のう ち 2 題, 【設問(5】と【設問6 【は二者択一の形式を とり，答えは一見単純である（例えば【設問(5】で は, 「昆虫の変態は進化か, 非進化か」など)。しか しながら，その二者にカテゴライズするに際して， そこに含む「根拠」を考えさせることで,「二項対立 による認知的不協和」を引き起こすという意図があ る（森本ら, 2006)。進化の学習は, 現実的な問いか けから梁めていくことができる効果的な教材であり， 科学の本質を指導するよい機会ともなりうる（高 橋・磯崎, 2014)。
もう1つの例として，【設問(6)のAはラマルク の「獲得形質の遺伝」を示し, 一生の間の変異が次 世代に遺伝することを意味している。これは現代進 化生物学では完全否定されているが, 高校・大学生 でも根強く保持している誤概念である（福井・鶴岡, 2001）。一方，Bはド・フリースの「遺伝・突然変異」 を示し, 現代進化学における学問の中心概念であり, ダーウィンの「自然選択説」を包含する「進化の総 合説」に依拠する科学概念である（Mayr, E., 1991 ; Charlesworth, B.\& D. , 2003 ; 粕谷，2005）。このよう に相反する両者を対峙させることによって，学習者 が「認知的不協和」を引き起し，その矛盾の解決過 程が生徒間の論争を促し，概念理解を促すように意 罒したものである（湯沢，2004）。表 3 には，各評価 の【観点】と共に【設問 (1)〜 (6)：回答例】として, 生徒たちから出てきた意見を参考のため簡略化して 掲載した。

\section{3 パフォーマンス課題の開発}

本授業計画における最終 6 時限目の総括的評価と しての「脊椎動物が水中から陸上へ進出した」こと を「文」章化する「パフォーマンス課題（文)」を準 備した。しかし，長文での表現は生徒が苦手とする 課題であり, その「文」課題に先立つ 5 時限目に, 図 2 のように「絵」で表現する「パフォーマンス課

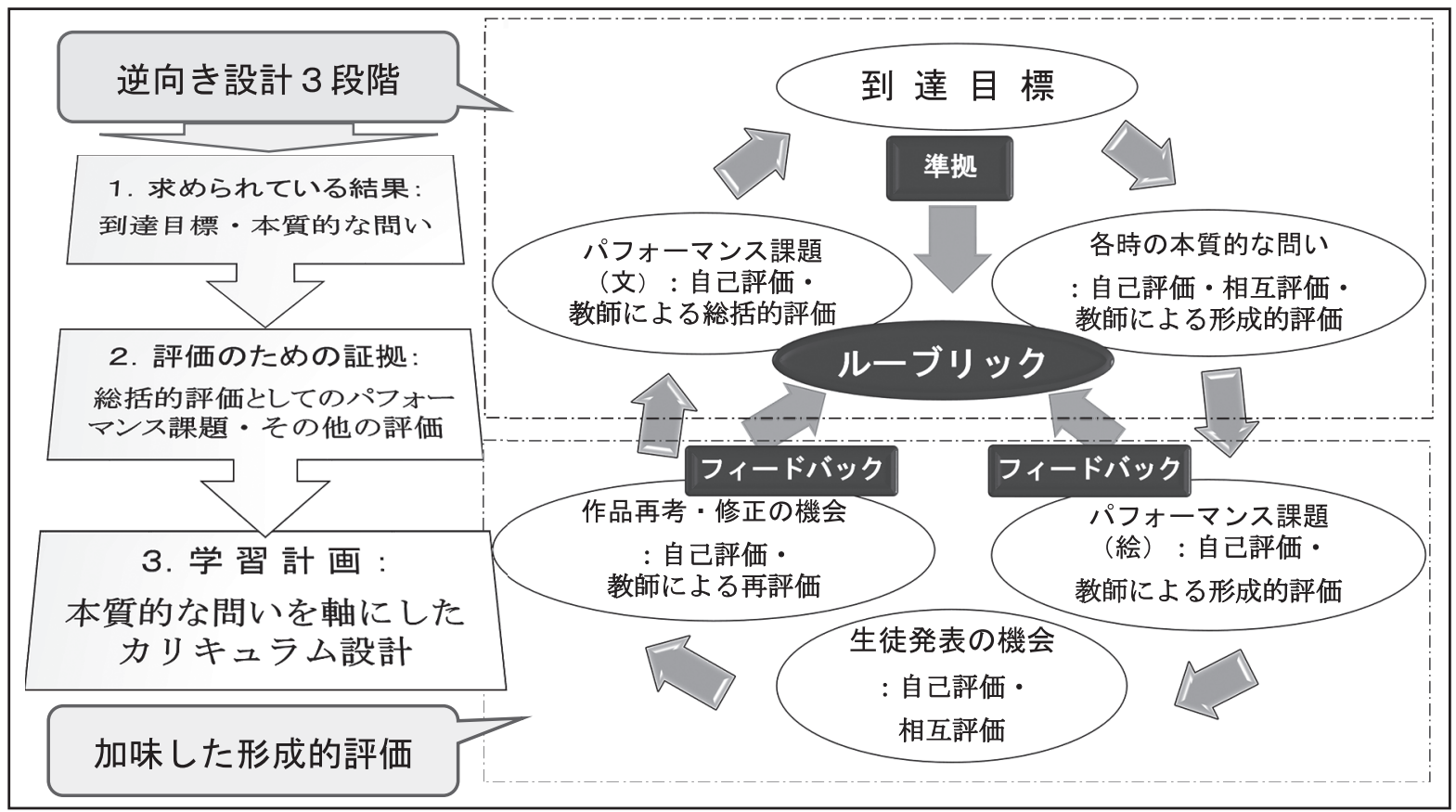

図 1 形成的評価を加味した教授・学習過程 
表 4 ルーブリック : 中学校 1 年地学分野

\begin{tabular}{|c|c|}
\hline 話価 & $\begin{array}{lll}\text { 評 価 指 標 } \\
\end{array}$ \\
\hline A & $\begin{array}{l}\text { 表 } 1 \text { の「到達目標」の1)・(2)の観点のうち } 2 \text { つが含 } \\
\text { まれ，それに関する進化の根拠（類縁関係など）が } \\
\text { 四や文で説明されている。 }\end{array}$ \\
\hline B & $\begin{array}{l}\text { 「到達目標」の1)・(2)の観点のうち } 1 \text { つが含まれ，そ } \\
\text { れに関する進化の根拠（類縁関係など）が図や文で } \\
\text { 説明されている。 }\end{array}$ \\
\hline C & $\begin{array}{l}\text { 「到達目標」の(1)・(2)の観点のうち } 1 \text { つが含まれてい } \\
\text { るが, それに関する進化の根拠（類縁関係など）が } \\
\text { 図や文で説明されていない。 } \\
\text { もしくは(1)・(2)の観点が全く含まれていない。 }\end{array}$ \\
\hline
\end{tabular}

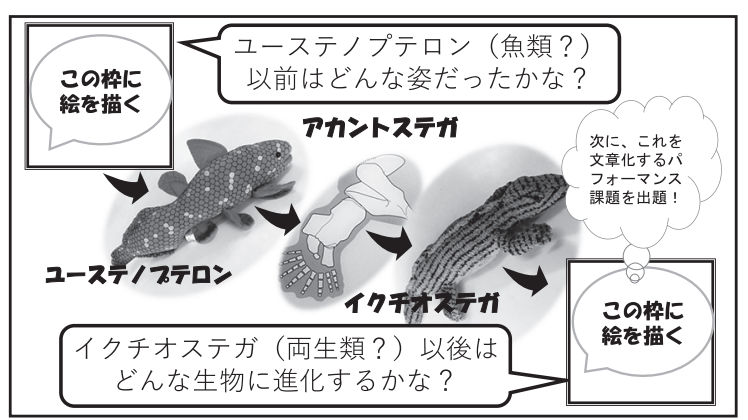

図 2 パフォーマンス課題 (絵) : 1 年地学分野

題」を開発し，その採点ツールとして表 4 の「ルー ブリック」も策定した。

このパフォーマンス課題は,「逆向き設計の 3 段階 (表 2)」の【第 2 段階】の(1)ある「実際の社会の 中で使える」ことを考慮し, 古生物学者などが「春 椎動物が水中から陸上へどのような進化を遂げたか」 について, 化石証拠や類縁関係から仮説を立てる手 法に基づいて考案したものである。加えて, 表 2 の 【第 2 段階】の(2)あたる「フィードバック」と, 同 じく(3にあたる「自己評価の機会」を確保した。さ らに【第 3 段階】の(2)あたる「再考し, 修正し, 洗練する十分な機会」を与えることによって,「重 大な概念の掘り下げに引き込まれる活動（1)にあた る)」を, パフォーマンス課題解決の前・後に組み込 んでいるのが，本授業開発の特長である。すなわち， 図 3 に示すように, この 5 時限後, 6 時限目の最初 が加味した「形成的評価」にあたる部分である。換 言すれば,「絵」と「文」の 2 つのパフォーマンス課 題の間に,「生徒発表」と「作品再考・修正」の機会 を配置し，これによって，一層文章化しやすい仕掛 けを確保した訳である。

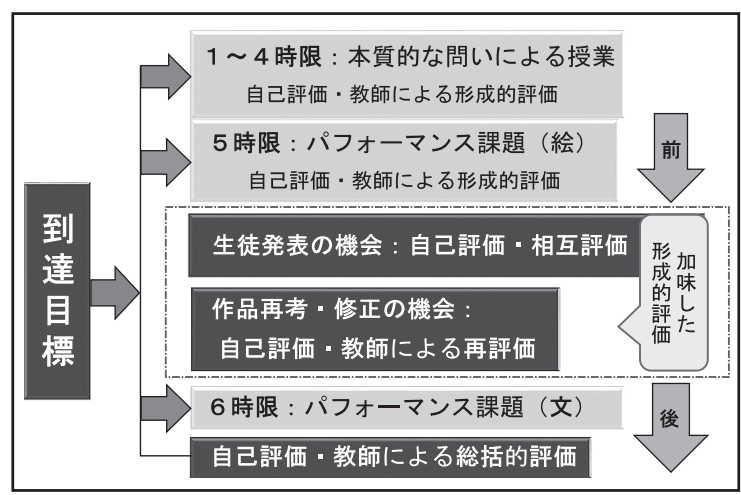

図 32 つのパフォーマンス課題の間の形成的評価

\section{3. 授業評価の方法}

\section{1 パフォーマンス課題による授業評価}

本研究において目的として設定した，中学生にお ける科学的進化概念の形成を達成するため, 脊椎動 物の陸上進出を，その前・後を含めて「絵」と「文」 でストーリー化するパフォーマンス課題（図 2）を 考案した。この課題は正解が1つでない, いわゆ る「オープンエンド」な課題である。そして,「到 達目標（表 1)」の達成度を測るッールとして「ルー ブリック（表4)」を用い, A・B・Cの 3 段階で 「絵」と「文」についてそれぞれ別個に評価した。パ フォーマンス課題において「絵」と「文」よる $2 つ$ の表現法をとったのは，そのことによって思考プロ セスが可視化され, 生徒の思考力や表現力を捉え ることが可能になると思われたからである（田中， 2011 ：戸田, 2012 ; 山地, 2010)。換言すれば, 魚類 (ユーステノプテロン) から両生類（イクチオステ ガ）へと進化する過程を，それら以前・以後の姿を 想像しながら「絵」で表現し, 次にその一連の進化 仮説を「文」章化することによって，思考・表現力 が一層明らかになると考えたからである。

先にも述べたが, 特に本研究では図 1 のように 「パフォーマンス課題 (絵)」を行った後,「生徒発 表」と「作品再考・修正」の機会を挟んで, 続いて 「パフォーマンス課題（文)」に取り組み，より文章 化が容易になるように工夫している（図 3)。すなわ ち，パフォーマンス評価を総括的評価として実施す るだけでなく，評価結果の即時的なフィードバック 効果を利用した「形成的評価」の要素を加味した訳 である（Bransford et al., 2000）。その評価結果の分析 によって, 本研究における授業開発が中学生の進化 概念形成に関してどの程度の有効かについて検討を 図ることがねらいである。 


\section{2 質問紙調査による授業評価}

質問紙調査（真偽法：○×式）によって，授業 前・後における科学的進化概念の形成とその理解度 に関する調査分析を行った。すなわち, 授業前・授 業後に表 5 にあるような質問を課し，それぞれ正答・ 誤答数を集計することによって, その変化から本研 究における授業開発の効果を検討した。質問ア〜 の 10 項目の概念抽出（特に誤解されやすい概念）に 際しては, 多くの先行実践における調査結果を下敷 きにして開発した（福井・鶴岡，2001；中井, 2004 ; 桐生, 2004 ; 宮本, 2008 ; 正本 - 西野, 2011)。具 体的に授業計画の中では, 表 3 の【設問(5)の8 枚 のカードのうち, カード(1)の「昆虫の変態」とカー ド8の「ヒトの成長」から「イ」の質問, カード(2) の「イチローの進化」とカード(4)の「ポケモンの進 化」から「ウ」の質問, カード(7)の「ケイタイの進 化」から「オ」の質問, カード(3)「ヒトの進化」

\section{表 5 質問紙調査（真偽法）：授業前・授業後調査}

「次のア〜コのうち，正しいと思われるものには○を，間 違っていると思うものには×を書きなさい。

ア．生物の世界では，かならず強いものが弱いものに勝 ち, 強いものが生き残っていく。

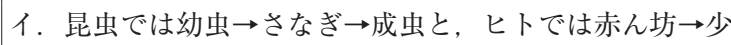

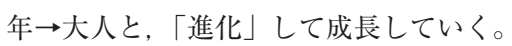

ウ.「鈴木一朗」選手は, プロ野球入団後 2 年目に「イチ ロー」と名乗ってから活躍が始まり，さらに大リーグ に移籍後も彼の野球の能力は「進化」し続けている。

工．地球上の生物は何億年も大昔から「進化」し, 動物で は地質年代の順に三葉虫, 恐竜, マンモスと変遷（変 化）してきた。

オ．電話はグラハム・ベルが発明してから，手回し式 $\rightarrow$ ダ イヤル式 $\rightarrow$ プッシュホン ーケイタイ電話 $\rightarrow$ スート フォンと「進化」し続けている。

カ.「進化」とは一世代で起きる変化ではなく, 長い世代 をへて起きる変化である。

キ，どんな生物でも，長い年月のあいだにすぐれた性質を もつものに「進化」してゆく。

ク．まわりの環境が変化すると，それにあった性質をもつ 生物が生き残っていく。たとえば, 恐竜は寒い環境に 「適応」できなかったので, 絶滅したと言われている。

ケ. 生物の「変異」は生きている間に起こり, その「変化 (変異)」が次世代に受け継がれていくことにより「進 化」が起こる。

コ. 生物の「変異」は新しく生まれ出るときに起こり, そ の「変化 (変異)」した生物がその時代の環境に「適 応」し，数多く生き残ることにより「進化」していく。

(以上 10 問)
とカード(5の「ユーステノプテロンからイクチオス テガへの進化」から「カ」の質問をそれぞれ概念抽 出した。また，表 3の【設問(1)・(2】から「エ」と 「ク」の質問,【設問6】から「ケ」と「コ」の質問 をそれぞれ導き出した。「ア」と「キ」の概念につい ては, ダーウィンの「自然選択説」が社会進化論的 な立場で「優れたものに進化する」と誤解されるた め（長谷川, 2004), 進化の学習によってこれらの䛊 解が減少するかを調査する質問であり, 特に本研究 の授業計画には組み込んでいない。

また,この質問紙の調査結果を集約するにあたり， 質問ア〜コの各内容について次のように熟語化して 整理した。すなわち，アの「生物の世界では，かな らず強いものが弱いものに勝ち，強いものが生き 残っていく」は「弱肉強食」の誤概念として, 簡略 化して集計表に記載した。以下同様に，イは「昆虫 の変態」を表す誤概念，ウは「ヒトの成長」を表す 誤概念，工は「大量絶滅」を表す正しい科学的進化 概念，才は「技術の進歩」を表す誤概念，カは「世 代性」を表す科学的進化概念, キは「優勝劣敗」を 表す誤概念, クは「環境適応」を表す科学的進化概 念, ケは「獲得形質の遺伝」を表す誤概念, コは 「遺伝・突然変異」を表す科学的進化概念，として集 計結果の簡素化と表化に役立てた。

\section{4. 調査結果とその分析}

\section{1 パフォーマンス課題による分析}

本研究では，授業計画 $5 \cdot 6$ 時限目（表 3）にあた る「パフォーマンス課題 (絵)」の後に,「生徒発表」 や「作品再考・修正」の機会を十分に確保した。こ れを本研究における「形成的評価を加味した教授・ 学習過程」として, 先の図 1 や図 3 に示し, 加味す る以前を「形成的評価前」, 加味した以後を「形成的 評価後」として以下の論を進める。

表 6 の「パフォーマンス評価 (絵)」の結果から, 「形成的評価」以前に比べ，以後においては A 評価 の生徒数に増加が見られた。これによって，自己 フィードバック効果や自己調整的な学習が促進され たものと考え，「形成的評価」の要素を加味したこと が原因と考察したいが，修正の機会を与えれば，評 価が上がるのは当然である。それでも，パフォーマ ンス課題（絵）においては過半数が, パフォーマン ス課題（文）においては半数が A 以上の評価に達し たことを考慮すれば, 中学生の科学的進化概念形成 に扔いて, 少なからずその概念理解が促進されたと 考えられる。

また,「ルーブリック（表 4)」の記載にあるよう 
に,「到達目標（表 1)」の観点が 1 つまたは 2 つ含 まれていても，それに見合う「根拠」すなわち「理 由付け」が適切でないために, $\mathrm{B}$ や $\mathrm{C}$ 評価になった 生徒もいた。例えば，水中から陸上へ進出するため には，その環境に適応して「ヒレが足」へ，「えら呼 吸が肺呼吸」へ, 徐々にその形態が変化することが 必要であるが，そのような「類縁関係に依拠する理 由」を記入せず，「歯の形」「体の大きさ」「ヒレの 数」「指の数」「肉食・草食」などにこだわって, 形 態変化の理由を数多く述べているものがいた。これ らの理由付けは，必ずしも上位の評価対象にならず, 評価が低いままの生徒が少なからずいた。そのよう な生徒であっても,「形成的評価」の要素を設ける ことによって，「根拠（理由）」の数が増えてきてい ることが予想された。そのため, 「生徒発表・作品 再考・修正 (図 3)」の前・後で「理由付け数」がど のように変化したかを延べ数で集計し，同じ表 6 に 掲げた。これを見ると, 評価の上昇は漸増程度とみ られるが，「形成的評価」以後はかなりの生徒が多 くの理由を挙げて, 自己の進化仮説を支えようとし たことが見て取れる。この傾向は表 7 のように「パ フォーマンス評価（文)」でも同様に現れ, 評価 $\mathrm{A}$ の生徒では平均約 7 個近くの「理由」を述べ, 評価 B の生徒でも平均 4 5 個の「理由」を挙げて自説の 正当性を主張しようと試みたことが分かった。

参考のために, 本研究に抒ける総括的評価であ る「パフォーマンス課題 (文)」において, どんな記

表 6 パフォーマンス評価（絵）

(2017 年 2 学級: $N=62)$

\begin{tabular}{|c|c|c|c|c|c|}
\hline 評価 & $\begin{array}{c}\text { 「形成的 } \\
\text { 評価」前 } \\
\text { 〔人〕 }\end{array}$ & $\begin{array}{c}\text { 理由付け } \\
\text { 数 } \\
\text { 〔人〕 }\end{array}$ & $\begin{array}{c}\text { 「形成的 } \\
\text { 評価」後由俚由け } \\
\text { 〔人〕 }\end{array}$ & $\begin{array}{c}\text { 付 } \\
\text { 数 } \\
\text { 〔人〕 }\end{array}$ & $\begin{array}{c}\text { 百分率 } \\
\text { 〔\%〕 }\end{array}$ \\
\hline A & 29 & 117 & 35 & 225 & 56.5 \\
\hline B & 29 & 66 & 24 & 112 & 38.7 \\
\hline C & 4 & 1 & 3 & 5 & 4.8 \\
\hline 合計 & 62 & 184 & 62 & 342 & 100.0 \\
\hline
\end{tabular}

表 7 パフォーマンス評価（文）

(2017 年 2 学級 : $N=62)$

\begin{tabular}{|c|c|c|c|c|}
\hline 評価 & $\begin{array}{c}\text { 評価人数 } \\
\text { 〔人〕 }\end{array}$ & $\begin{array}{c}\text { 理由付け数 } \\
\text { 〔人〕 }\end{array}$ & $\begin{array}{c}\text { 1 人当たりの } \\
\text { 平均理由付け数 } \\
\text { 〔個〕 }\end{array}$ & $\begin{array}{c}\text { 百分率 } \\
\text { 〔\%〕 }\end{array}$ \\
\hline A & 31 & 211 & 6.8 & 50.0 \\
\hline B & 24 & 109 & 4.5 & 38.7 \\
\hline C & 7 & 9 & 1.3 & 11.3 \\
\hline 合計 & 62 & 329 & 5.3 & 100.0 \\
\hline
\end{tabular}

述（理由付け）が見られたか，その典型的な回答例 について表 8 に記載した。表 8 より「パフォーマン 久課題（文)」でも，「形成的評価を加味した教授 . 学習過程（図 1)」の効果を示唆するような傾向が見 られたと考えることができる。しかしながら，複数 の「理由付け」を記入しているにも関わらず，必ず しもそれが高い評価に結びついているとは言えない。 「ルーブリック（表 4)」から考えても，A 評価を得 るためには,「到達目標（表 1)」の観点 2 つを記入 した上で，それぞれについてその観点に関連した 1

\section{表 8 「パフォーマンス課題（文)」の回答例}

【「パフォーマンス課題（絵)」で描いた各自の仮説（以下の (1)と(5)にあたる) に基づいて，水中から陸上への長い世代 (以下の(2)ユーステノプテロン〜 (4)イクチオステガ) を経 て，環境に適応して進化したストーリーを文章化する課題】 (1)ユーステノプテロン以前（仮説）：古生代（約 4 億年前 など）の海（深海・海底など）では，水圧に耐える皮膚 （硬い鱗の甲贯魚・鱗のない平べったい形など）に覆われ， ヒレも水圧のため太い筋肉（またはほとんど無い）。暗い ため目は未発達（逆に吸光のため大きい）。主にエラで呼 吸する。この中で，長い年月を経て，ヒレを使って海底を 歩くことができるものが出現し，ユーステノプテロンへと 進化した。

(2)ユーステノプテロン（魚類）：浅瀬（淡水など）にすみ, 普段はエラ呼吸。浮袋を使って肺でも呼吸でき，骨のある 太いヒレを持っていたので，ときどき餌を探しに陸上へ這 い上がることもあった。

(3)アカントステガ（両生類）：しだいに骨のある太いヒレ が，指のある足（脚）に進化したが，四肢は短くやや体側 につき，腹が地面に接近していた。そのため陸上を駆け回 るのは苦手で，水辺に暮らしていた。そのうち長い世代を 経て，踏ん張れる四肢をもつものが現れた。

(4)イクチオステガ（両生類）：(約 3.6 億年前）水辺にすみ, 水かきがあり，うまく泳ぐこともできたが，一方でしっか りした四肢と骨格を持ち, 陸上でも安定していた。肺呼吸 をし，バランスを取るため太い筋肉の，長い尾をもってい たため自由に陸上を歩くことができた。

(5)イクチオステガ以後（仮説）：中生代（約 2.5 億年前な ど）の陸上環境（岩場・草原・湿地帯など）では，寒さ・ 暑さや乾燥に耐える皮覤（甲羅・厚い鱗・毛皮・厚い皮下 脂肪など）を持ち，重力に耐える（逃げる・獲物を追う） ため, 骨格や筋肉が発達した脚と, その他（平衡をとるた めの長い尾・広い視野の目または獲物を狙う前向きの目・ 陸での砂を防ぐためのまつ毛・鋭い肉食の歯・保護色の皮 膚など）を持っていた（以上の(1)（5)のように，水中から 陸上への進化の流れにそった内容が，長い世代にわたって 少しずつ変化していくように記入されていれば, 「A」評 価である)。 
つずつの「理由付け」でも十分である。これは評価 に直結しないような「理由付け」を過剩に記載した 生徒が, 一定数存在したことが原因であると考えら れる。

\section{2 質問紙調査による分析}

授業前・授業後における質問紙調査（表 5) に よって，その正答数と誤答数をそれぞれ集計し，そ こから中学生の科学的進化概念形成の変化を明らか にし, 本授業計画の効果を検討した。表 9 に質問紙 調査の回答結果（各質問項目についての正答数と誤 答数) を示した。加えて, 回答結果の分析に際して はア〜コの 10 項目について, 対応のある比率の差を 検定するため, 1 項目ずつマクネマー検定を行った。 この検定による分析結果についても, 同様に表 9 の 右端に記載した。

表 9 より「イ 昆虫の変態」「ウ ヒトの成長」「オ 技術の進歩」「力 世代性」「ケ 獲得形質の遺伝」 $「$ 遺伝・突然変異」の 6 項目については, 有意水 準 $5 \%$ で授業前・後での有意差が見られた。すなわ ち, この 6 項目については, 授業前から授業後にか けて正答率が上昇したことが明らかになった。他の 4 項目「ア」「エ」「キ」「ク」については, 有意差は 見られなかった。

本研究では,「授業計画（表 3)」における【設問 (5)のように, 「進化か, 非進化か」の 2 グループに 分ける課題を提示した。そこでは,「イ 昆虫の変 態」「ウ ヒトの成長」「オ 技術の進歩」など誤用 例が含まれている。授業展開はパフォーマンス課題 のみならず, 各時間においても正解の定まらない単 元を貫く「本質的な問い」を積み上げていく形式で あり, 原則として正解は生徒が出していくという方 針とっている。そのため, あえて正解は明示しない し, 正答を覚えるような指示も出さない。そのこと に鑑みても,「本質的な問い」の効果が示唆される結 果であった。また，同様に「授業計画」の【設問(6】 においても,「ケ 獲得形質の遺伝」と「コ 遺伝・ 突然変異」を対峙させ,「コ」の科学的概念へ導か れるような「対話的な学び」を展開している。冒頭 でも述べたように「獲得形質の遺伝」は保持されや すく, 根強い誤概念であるが, 授業開発による一定 程度の効果と見て取ることができる。「カ世代性」 については, パフォーマンス課題の「到達目標（表 1)」には「生物進化は一世代で起こらず, 長い世代 を経て起こる変化」と明記されているため, 正答率 に上昇が見られるのは妥当な結果であると思われる。

一方, 「ア 弱肉強食」や「キ 優勝劣敗」につい
表 9 質問紙調査授業前・後における回答結果

(2017 年 2 学級: $N=60)$

\begin{tabular}{|c|c|c|c|c|c|c|}
\hline & \multirow{2}{*}{ 各質問項目 } & \multicolumn{2}{|c|}{ 授業前〔人〕 } & \multicolumn{2}{|c|}{ 授業後〔人〕 } & \multirow{2}{*}{$\begin{array}{l}\text { マクネマー } \\
\chi^{2} \text { 検定結果 }\end{array}$} \\
\hline & & 正答数 & 誤答数 & 正答数 & 誤答数 & \\
\hline ア & 弱肉強食（誤） & 39 & 21 & 43 & 17 & n.s. \\
\hline 1 & 昆虫の変態（誤） & 18 & 42 & 46 & 14 & $* *$ \\
\hline ウ & ヒトの成長（誤） & 8 & 52 & 52 & 8 & $* *$ \\
\hline 工 & 大量絶滅（正） & 51 & 9 & 54 & 6 & n.s. \\
\hline 才 & 技術の進歩（誤） & 5 & 55 & 24 & 36 & $* *$ \\
\hline 力 & 世代性（正） & 49 & 11 & 58 & 2 & $* *$ \\
\hline キ & 優勝劣敗（誤） & 32 & 28 & 28 & 32 & n.s. \\
\hline ク & 環境適応（正） & 57 & 3 & 59 & 1 & n.s. \\
\hline ケ & 獲得形質の遺伝（誤） & 24 & 36 & 42 & 18 & $* *$ \\
\hline$\exists$ & 遺伝・突然変異（正） & 41 & 19 & 50 & 10 & $*$ \\
\hline
\end{tabular}

$\mathrm{df}=1 \quad \chi_{.05}^{2}=3.841 \quad(* p<0.05) \quad \chi_{.01}^{2}=6.635 \quad(* * p<0.01)$ n.s. (not significant)

ては, 本研究における 1 年地学分野の授業では特に 取り上げていない。これについては，本来は生物分 野で取り上げるべきものであり，ここで正答率に伸 びが見られないのは授業計画の問題だけではないと 考えられる。

加えて, 同様に有意差が見られなかった「エ大 量絶滅」「ク 環境適応」については, 元々正答数 が多く，授業後での増加が見込まれないためである と考えられる。「環境適応」については,「授業計画 (表 3)」の 2 限目終了時における質問紙調查の直前 に,【設問(4)で「生物と環境との関連」について考 えさせている。さらに，各地質年代の「大量絶滅」 については，1限目に【設問(1】や【設問(2】で「地 球環境と体のつくり」について考えさせている。つ まり，質問紙調査をする以前に，「環境適応」や「大 量絶滅」に関する学習がなされているため正答数が 高かったと考えられる。

\section{5. まとめと今後の課題}

\section{本研究によって次のことが明らかになった。}

先の 4.1 の「パフォーマンス課題による分析」か ら,「形成的評価」の要素を設けることによって, 次 第に挙げる「根拠（理由）の数」が増えてくること が判明した。また, パフォーマンス課題（絵）にお いては最終的に過半数が, パフォーマンス課題（文） においては, 約半数が $\mathrm{A}$ 評価に達した。このことか ら, パフォーマンス課題 (絵・文) やそれに付随す る「本質的な問い」のみならず，「形成的評価」によ る授業計画が生徒の言語活動を少なからず促進した ことが示唆される。すなわち，再考や修正の機会な どを与えることが中学生の課題追究において興味を 
持続させ，深く考えることにつながったと考えられ る。ただし，形成的評価「前・後」における，「理由 付け」の数は上昇しているが, 各段階の評価そのも のの上昇はごくわずかであった。これは「到達目標 (表 1)」や「ルーブリック（表4)」において,「評 価」と「理由付け」の両者が適切に関連付けられて いないためであると考えられる。この改善と工夫が 今後の筆者らの課題である。

また， B・C 評価の生徒の中には，一部であるが, 「海から陸に出ようとして努力した結果が後の陸上 進出につながった」とする「獲得形質の遺伝」に類 する記述が 7 名程度存在した。これは本研究におけ るパフォーマンス評価に直結しないため, 集計結果 には反映されなかったが，授業後の質問紙調査の集 計結果（表 9 の「ケ」）とほぼ一致する結果である。 今後,「獲得形質の遺伝」についての証拠を探って いくような授業実践の開発も, 残された研究課題と なった。

次に, 4.2 の「質問紙調査による分析」から，「昆 虫の変態」「ヒトの成長」「技術の進歩」「世代性」 「獲得形質の遺伝」「遺伝・突然変異」の 6 項目につ いて, 授業後の正答率において有意に増加がみられ た。すなわち，これらの 6 つの進化概念については， 本研究における授業計画によって生徒の科学的概念 理解の形成を促したことが示唆される。特に, 先行 研究において保持されやすいとされてきた, 「獲得形 質の遺伝」において有効であったことは特筆すべき ことである。「弱肉強食」「優勝劣敗」の 2 項目につ いては有意差が出なかった。この中学校 1 年地学分 野の授業ではこれらの 2 項目について理解促進を図 る仕掛け，すなわち「本質的な問い」は計画されて いなかったためである。また,「大量絶滅」「環境適 応」の 2 項目については, 質問紙調査前に既に学習 されていたため授業前から正答率が高く, 天井効果 がうかがわれる。

\section{付記}

本論文は, 平成 25（2013）年度大阪教育大学大学 院教育学研究科実践学校教育専攻に提出の修士論文 「中学校理科における生物進化の指導方略の開発に関 する実践的研究一『進化』を中 1 から段階的に学習 する試み一」を基本とし, 日本理科教育学会第 67 回 全国大会（2017）における発表内容を, 筆者らの最 新の研究調査結果を踏まえた上で, 大幅に加筆・修 正を加えたものである。

\section{引用文献}

Bransford, J.D., Brown, A.L., \& Cooking, R.R. (Eds.). (2000). How People Learn Brain, Mind, Experience, and School. Washington, DC: National Academy Press.

Charlesworth, B., \& Deborah (2003). Evolution: A Very Short Introduction, Oxford: Oxford University Press. (石川統訳 （2005）『一冊でわかる進化』岩波書店 .)

遠藤貴広（2005）「G．ウィギンズのカリキュラム論におけ る『真正の評価』論と『逆向き設計』論の連関」『京 都大学教育学研究科紀要』第 51 号, 262-274.

福井智紀・鶴岡義彦（2001）「主要な進化学説についての生 徒の捉え方に関する研究」『理科教育学研究』第 42 巻, 第 1号, 1-11.

長谷川賉理子（2004）「進化を教える難しさ一進化の正し い理解の普及に向けて一」『遺伝』第 58 巻, 第 4 号, $78-81$.

石川聡子・森一夫 (2002)「理科教育に現れる時代思潮の影 響」『大阪教育大学教科教育学論集』創刊号, 1-9.

粕谷英一（2005）「進化生物学の成立」石川統（編）『進化 学の方法と歴史』岩波書店, 22-63.

桐生尊義（2004）「中学校でどのように進化を教えるか?」 『遺伝』第 58 巻, 第 4 号, 35-39.

正本安心・西野秀昭（2011）「中学校理科に打ける植物を 中心とした生物進化授業の展開」『福岡教育大学紀要」 第 60 巻, 第 3 号, 43-54.

Mayr, E. (1991). One Long Argument: Charles Darwin and The Genesis of Modern Evolutionary Thought. Cambridge: Harvard University Press. (養老孟司訳（1996）『ダーウィ ン進化論の現在』岩波書店).

宮本俊彦（2008）「中等教育段階の生徒における生物進化に 対する認識の現状と進化概念形成への人類学学習の効 果」『日本人類学会』第 116 巻, 第 2 号, 194-198.

文部科学省 (2008)「平成 20 年告示 中学校学習指導要領」 文部科学省 (2017)「平成 29 年告示 中学校学習指導要領」 森本弘一（2009）「体験活動を通して生物好きにする手立 て」理科教育研究会編『新学習指導要領に応える理科 教育』東洋館出版社, 160 .

森本信也・甲斐初美・森藤義孝（2006）「理科授業における 学習者の科学概念変換に関する一考察一中学生の進化 に関わる概念変換を事例にして一」『理科教育学研究」 第 47 巻, 第 2 号, 51-63.

中井咲織（2004）「小学生でもすぐわかる進化の教え方一中 等教育での発想の転換に向けて一」『遺伝』第 58 巻, 第 4 号, 56-66.

西岡加名惠 (2005)「ウイギンズとマクタイによる『逆向き 設計』論の意義と課題」『カリキュラム研究』第 14 号, $15-29$.

西野秀昭・佐竹晃一（2013）「中学校理科生物領域に扔ける 進化概念を取り入れた実践的授業の構築」『福岡教育 大学紀要』第 62 号, 第 3 分冊, 27-49. 
佐藤崇之 · 大鹿聖公 (2005)「教科書分析と教材研究から見 た高等学校生物における進化の単元に関する一考察」 『広島大学大学院教育学研究科紀要』第 2 部, 第 54 号, $17-24$.

高橋一将・磯崎哲夫（2014）「BSCSにおける進化学の特 色」『理科教育学研究』第 54 卷, 第 3 号, 369-381.

田中耕治（2011）『パフォーマンス評価一思考力・判断力・ 表現力を育む授業づくり一』ぎょうせい, $2-8$.

戸田尚義（2012）「表現活動の充実とルーブリックを活用し た形成的評価」『東京教育研究所 研究報告』第 240 号, 24-29.

塚田捷ら（2016a）『未来へひろがるサイエンス 1』（中学校 理科用）新興出版社啓林館 塚田捷ら（2016b）『未来へひろがるサイエンス 2』（中学校 理科用）新興出版社啓林館

山地正樹 (2000)「実践事例 $2 」$ 香川大学教育学部付属高松 小学校編『活用する力を育むパフォーマンス評価』明 治図書, 59-61.

Wiggins, G., \& McTighe, J. (2005). Understanding by Design, ASCD. (西岡加名惠訳 (2012)『理解をもたらすカリ キュラム設計』日本標準 .)

湯沢正通（編著）（2004）『認知心理学から理科学習への提 言』. 北大路書房, 第 1 部 $-1,2-22$.

(2017 年 11 月 30 日受付, 2018 年 3 月 19 日受理) 


\title{
Development of a Science Lesson Incorporating Performance Tasks with Formative Assessment \\ -Regarding Concept Formation of Scientific Evolution in Lower Secondary School-
}

\author{
Masami NAGURA ${ }^{1}$, Shinji MATSUMOTO ${ }^{2}$ \\ ${ }^{1}$ Osaka Municipal Shimofukushima Lower Secondary School (United Graduate School \\ of School Education, Hyogo University of Teacher Education) \\ ${ }^{2}$ Hyogo University of Teacher Education
}

\begin{abstract}
SUMMARY
Fossil materials with photographs, which are evidence of evolution from the Paleozoic to the Cenozoic Era, are published in science textbooks for lower secondary school first graders. However, there is no explanation of "how all living things have evolved"; only the results of evolution are enumerated. On the other hand, there are many misunderstandings concerning "evolution", and many previous studies have pointed out the misconceptions that are persistently retained. Therefore, the purpose of this paper was to examine to what extent the evolutionary concepts of lower secondary school students were formed by the lesson we developed. Specifically, we set up "essential questions" on evolution every hour in the lesson, and we prepared "performance tasks" to be expressed via "pictures" and "sentences" as the summative assessment. Furthermore, before and after the students created the performance tasks, we gave them opportunities to rethink and revise them through active learning. In other words, the elements of formative assessment such as mutual peer assessment were added to the teaching and learning process. Our analysis based on the performance tasks and the results of our questionnaire survey showed a certain effectiveness in fostering understanding of the evolutionary concepts in the lower secondary school students.

$<$ Key words $>$ Earth Science in Lower Secondary School, Evolutionary Concept, Backward Design, Performance Task, Formative Assessment
\end{abstract}

